\title{
Rice Bran Based Vitabran Sports Vitality Booster
}

\author{
Oktia Woro Kasmini Handayani ${ }^{1}$, Arif Rahmad Kurnia ${ }^{2}$ \\ \{oktia2016@mail.unnes.ac.id ${ }^{1}$, Arifrahmatk@gmail.com² \\ Universitas Negeri Semarang, Semarang, Indonesia ${ }^{1,2}$
}

\begin{abstract}
The local food ingredients also function as a functional food. They are rich in nutrients and have a low GI, such as rice bran and sweet potato flour. The research objective was to analyze the benefits of Vitabran, a mixture of rice bran and sweet potato, for health.The process begins with rice bran flour manufacture, followed by making Vitabran selected from 3 formulas, organoleptic test, hedonic test, and proximate test. The selected formula was then tested for GI, with a bran composition of $20 \%, 40 \%$ yellow sweet potato, $14 \%$ cornstarch, $10 \%$ soy milk, $10 \%$ margarine, $5 \%$ honey, one egg, $1 \%$ baking powder, oats to taste. The selected Vitabran formula contains $63.214 \%$ carbohydrates, $10.756 \%$ protein, $6.26 \%$ fat, $0.09 \%$ water, $17.44 \%$ ash, and $2.232 \%$ crude fiber. One piece of Vitabran measuring $12 \times 3 \times 2 \mathrm{~cm}$, weighing 75 grams contains 264 calories, a moderate GI category (65), and usable as a Sports Vitality Booster.
\end{abstract}

Keywords: Glycemic Index, Local Food Ingredients, Functional Food, Sports Vitality Booster.

\section{Introduction}

Nutritional needs that come from food consumption to generate energy in sports activities are urgent and need attention. The primary energy source obtained from carbohydrates will harm health if fulfilled from the wrong food selection. It will have an impact on exacerbating the increase in cases of degenerative diseases, including diabetes mellitus. According to WHO, DM cases have experienced an alarming increase as WHO predicted that by 2040 the number of DM sufferers would reach 642 million. Around 366 million adults will be diabetes in 2030, where $75 \%$ of sufferers locate or live in developing countries. Some research show food sources existing in one area (local) can be used as a functional food. They have a low GI value. So they can reduce or suppress the excessive consumption of wrong foods and their long-term effects.

These foods include bran flour, yellow sweet potato (Ipomoea batatas): [1,2,3,4,5]. Bran flour is a byproduct of rice processing that contains many nutrients such as fiber, minerals, vitamin B complex, vitamin E, essential fatty acids, and amino acids, as well as antioxidants: $[6,7,8]$. The composition of the bran flour contains $34 \%-62 \%$ carbohydrates, $15 \%-20 \%$ lipids, $11 \%-15 \%$ protein, $7 \%-11 \%$ fiber, and minerals, such as phosphorus $1.5 \%-$ $1.7 \%$, potassium $1.4 \%-1.5 \%$, Magnesium $0.78 \%$, Calcium $0.02 \%$, and contains strong antioxidants. The magnesium content in bran flour can improve glycemic control, prevent insulin resistance, and strong antioxidant content. They can help manage diseases associated with oxidative stress, such as diabetes mellitus: [4,5].

The nutritional content of yellow sweet potato (Ipomoea batatas) per 100 grams is: 20.12 grams of carbohydrates, 1.57 grams of protein, 3 grams of fiber, 0.05 grams of lipids, 
vitamins such as Thiamin, Riboflavin, Niacin, B6, B9, vitamin C, vitamin $\mathrm{K}$ and most is vitamin A $14187 \mathrm{IU}$, mineral content such as Calcium $30.78 \mathrm{mg}$, Iron $0.61 \mathrm{mg}$, Magnesium $25.70 \mathrm{mg}$, Phosphor $47.81 \mathrm{mg}$, Potassium $337 \mathrm{mg}$, Sodium $55 \mathrm{mg}$. The effect of lowering blood glucose in sweet potatoes is associated with increased adiponectin levels. It is an adiposity hormone that functions as a process of insulin metabolism: [2].

The research problems are: 1) How is the acceptance of target consumers for products related to the organoleptic test and hedonic test at bran levels of $20 \%$ and $30 \%$ with yellow sweet potato substitution. 2) What are the proximate product test results at bran content of $20 \%$ and $30 \%$ with yellow sweet potato substitution. 3) Which product formula to recommend as Vitabran. 4) What is the value of IG Vitabran.

\section{Methods}

The staple ingredients are rice bran with a mixture of yellow sweet potatoes, cornstarch, soy milk and wheat flour, eggs, honey, baking powder, margarine, and oats. The equipment used consists of a microwave oven, Otoclaf, sieve, oven, gas stove, cake toaster. We test the VITABRAN formula with two kinds of bran content, namely $20 \%$ and $30 \%$.

The making bran flour process by 1) selected fresh and clean bran, sieved with a diameter of 80 Mesh 2) sterilized by autoclave at $121 \mathrm{C}$ for 3 minutes, dried in $105 \mathrm{C}$ oven, for 1 hour. VITABRAN production process by mixing the formula into a formable dough. Then formed a bar with a $12 \times 3 \times 2 \mathrm{~cm}$ size and sprinkled with oats, then baked in the oven.

Table 1. VITABRAN Formula

\begin{tabular}{llcc}
\hline No & \multicolumn{1}{c}{ Ingredients } & Formula 1 & Formula 2 \\
\hline 1. & Rice bran & $20 \%$ & $30 \%$ \\
\hline 2. & Yellow potatoes mix & $40 \%$ & $30 \%$ \\
\hline 3. & Cornstarch & $14 \%$ & $14 \%$ \\
\hline 4. & Soy milk & $10 \%$ & $10 \%$ \\
\hline $\mathbf{5 .}$ & Baking powder & $1 \%$ & $1 \%$ \\
\hline 6. & Margarine & $10 \%$ & $10 \%$ \\
\hline 7. & Honey & $5 \%$ & $5 \%$ \\
\hline 8. & Oats & Sown to taste & Sown to taste \\
\hline
\end{tabular}

The researcher carried out the bran flour processing, VITABRAN products, and GI measurements at the UNNES Nutrition Laboratory. For proximate analysis at the UNNES Biology Laboratory. It consists of checking moisture and ash content (oven method): [9], protein content (Kjeldahl Micro method): [9], fat content (Soxhlet method): [9], carbohydrate by difference: [9], Analysis of dietary fiber content: [10]. Sensory analysis with trained panelists aged 25-40 years, a total of 10 panelists (5 males and females), the quality scales consisting of 9 points (very low to very very good), and following standard procedures: [11]. The aspects assessed were color, texture, sweetness, aroma, and overall quality. Sensory 
analysis was assessed for three repetitions, with a time lag of 30 minutes. The product preference rating was determined by 80 panelists, with the acceptability test (preference scale 1 - 9): [11,12].

A panel of 10 adult volunteers ( 5 men and women) performed the GI analysis. The analysis by t-test using SPSS 16.0. to compare the GI of the reference food with the GI of the treated food

\section{Result and Discussion}

Based on the data obtained, the results of the sensory quality assessment, overall formula two biscuits with a higher value (53), as well as the total (309), while the highest value was in the aroma aspect (55) according to Table 2.

Table 2. Result of Sensory Quality Assessment (Organoleptic Test)

\begin{tabular}{cccccccc}
\hline $\begin{array}{c}\text { Product } \\
\text { Assestment }\end{array}$ & Overall & Color & Aroma & $\begin{array}{c}\text { Texture/ } \\
\text { crispness }\end{array}$ & Sweetness & $\begin{array}{c}\text { Yellow Potatoe } \\
\text { Taste }\end{array}$ & Total \\
\cline { 2 - 8 } & 1 & 2 & 3 & 4 & 5 & 6 & 7 \\
\hline Biscuit bar 1 & 49 & 46 & 48 & 44 & 45 & 45 & 277 \\
\hline Biscuit bar 2 & 53 & 49 & 55 & 52 & 47 & 53 & 309 \\
\hline
\end{tabular}

The favor value or the hedonic test results as a whole were the highest in the biscuit formula 2 (503). The overall aspect value was found in the biscuit formula 2 (2962), while the highest value was in the aroma aspect (515), according to Table 3.

Table 3. Result of Hedonic Test Assestment

\begin{tabular}{cccccccc}
\hline $\begin{array}{c}\text { Product } \\
\text { Assestment }\end{array}$ & Overall & Color & Aroma & $\begin{array}{c}\text { Texture/ } \\
\text { crispness }\end{array}$ & Sweetness & $\begin{array}{c}\text { Yellow Potatoe } \\
\text { Taste }\end{array}$ & Total \\
\cline { 2 - 8 } & 1 & 2 & 3 & 4 & 5 & 6 & 7 \\
\hline Biscuit bar 1 & 488 & 484 & 438 & 429 & 447 & 475 & 2761 \\
\hline Biscuit bar 2 & 503 & 495 & 515 & 509 & 458 & 482 & 2962 \\
\hline
\end{tabular}

In the proximate test results, the carbohydrate, protein, and fat content was higher in formula 2 biscuits while the water, ash and crude fiber content was higher in formula 1 biscuits (Table 4).

Table 4. Proximate Test Results

\begin{tabular}{cccccccc}
\hline No & Sample Code (\%) & $\begin{array}{c}\text { Carbohydrate } \\
(\boldsymbol{\%})\end{array}$ & $\begin{array}{c}\text { Protein } \\
(\boldsymbol{\%})\end{array}$ & $\begin{array}{c}\text { Fat } \\
(\boldsymbol{\%})\end{array}$ & $\begin{array}{c}\text { Water } \\
(\boldsymbol{\%})\end{array}$ & $\begin{array}{c}\text { Ash } \\
(\boldsymbol{\%})\end{array}$ & $\begin{array}{c}\text { Crude Fiber } \\
(\boldsymbol{\%})\end{array}$ \\
\hline $\mathbf{1}$ & 1 & 63.214 & 10.756 & 6.26 & 0.09 & 17.44 & 2.232 \\
\hline $\mathbf{2}$ & 2 & 68.569 & 11.273 & 6.62 & 0.08 & 13.02 & 0.446 \\
\hline
\end{tabular}

The Vitabran biscuit selected for the IG test is the formula two biscuits, considering that they are acceptable to target consumers. The resulting Vitabran contains $63.214 \%$ 
carbohydrates, $10.756 \%$ protein, $6.26 \%$ fat, $0.09 \%$ water, $17.44 \%$ ash and $2,232 \%$ crude fiber. One slice of Vitabran produced (bar-shaped with a $12 \times 3 \times 2 \mathrm{~cm}$ size) weighing 75 grams contains 264 calories. The Glycemic Index obtained is in the medium category or 65 .

The biscuit formula chosen for the GI test on panelists is the most acceptable formula for consumers, namely biscuit formula 2 . The glycemic index is the speed at which blood sugar levels rise after consuming food. It is equivalent to $50 \mathrm{~g}$ of carbohydrates: $[13,14]$. The increase in blood sugar rate is different for each food-stuff. It is classified into low GI <55, medium GI 55-70, and high GI> 70. Fast-processed carbohydrates during digestion have a high GI, whereas slow-processed carbohydrates release glucose into the bloodstream slowly so that a low GI: [15].

The results of GI examination in volunteers were obtained in the moderate category or as large as 65. It is possible because of the synergistic effect of the overall composition of Vitabran: [16], such as the results of a study which stated that rice bran contains $34 \%-62 \%$ carbohydrates, $15 \%-20 \%$ fat. , protein $11 \%-15 \%$, fiber $7 \%-11 \%$, minerals, such as Phosphorus, Potassium, Magnesium, Calcium, and strong anti-oxidants: [3, 4]. The results of other studies suggest that bran prolongs the period of glucose release and shows the potential to increase satiety: $[17,18]$. Meanwhile, the addition of the yellow potatoes mixture is referred to the results of similar research. It states that the nutritional content of sweet potatoes per 100 grams includes calories $(86 \mathrm{kcal})$, carbohydrates $(20.1 \mathrm{~g})$, fat $(0.1 \mathrm{~g})$, protein $(1.6 \mathrm{~g})$, fiber $(1.7 \mathrm{~g})$, high in vitamin A $(709 \mu \mathrm{g})$, high in the mineral potassium $(337 \mathrm{mg})$. Or other proximate analysis results of yellow sweet potato per 100 grams are: $20.12 \mathrm{~g}$ carbohydrates, $1.57 \mathrm{~g}$ protein, $3 \mathrm{~g}$ fiber, $0.05 \mathrm{~g}$ lipids, various kinds of vitamins such as Thiamin, Riboflavin, Niacin, B6, B9, vitamin C, vitamin K and most is vitamin A 14187 IU, various minerals such as Calcium $30.78 \mathrm{mg}$, Iron $0.61 \mathrm{mg}$, Magnesium $25.70 \mathrm{mg}$, Phosphor $47.81 \mathrm{mg}$, Potassium $337 \mathrm{mg}$, Sodium $55 \mathrm{mg}$. Vitabran has the main ingredients of rice bran, and yellow sweet potato contains strong natural anti-oxidants. It helps treat and manage diseases associated with oxidative stress such as hypertension, atherosclerosis, diabetes, heart failure, and stroke: [3].

The content of the product from this research is called Vitabran. It contains high carbohydrates but with a Low Glycemic Index (LGI 51) value. It is a type of carbohydrate which, if consumed, will not increase blood sugar levels drastically. Based on the content obtained, Vitabran can be used as a Vitality Booster. Vitabran can be consumed as a snack or as a complementary food that can meet energy and protein needs, with the effect of preventing diabetes and other degenerative diseases in athletes in the future.

Vitabran is suitable for athletes, especially for physical fitness/physical fitness and health improvement. The usage of Vitabran can be a complementary food for athletes to build muscle mass and in sports achievements. The use of Vitabran is like eating regular snacks when needed or when feeling hungry before exercising or after exercising. As a snack, it is eaten several times a day and is taken along with activities (anytime) or an efficient substitute for large meals currently trending by the community. The requirement depends on the calorie needs of each individual. Based on age, gender, physical activity is undertaken and considering the diet that is carried out.

\section{References}

[1] Trisnawati, W. 2015. Pemanfaatan Tepung Bekatul dan Tepung Labu Kuning Sebagai Bahan Keripik Simulasi Kaya Serat dan Antioksidan. (Disertasi). Pascasarjana. Universitas Udayana, Denpasar. 
[2] Taiwo Betty Ayeleso1, Khosi Ramachela2 and Emmanuel Mukwevho1. 2016. A review of therapeutic potentials of sweet potato: Pharmacological activities and influence of the cultivar. Tropical Journal of Pharmaceutical Research December 2016; 15 (12): 2751-2761

[3] Manali Chakraborty, Savita Budhwar, Pooja and Vinod. 2018. Nutritional and therapeutic value of rice bran. IJGHC, June 2018 - August 2018; Sec. A; Vol.7, No.3, 451-461.

[4] Bhagavathi Sundaram Sivamaruthi, Periyanaina Kesika, Chaiyavat Chaiyasut. 2018. A comprehensive review on anti-diabetic property of rice bran. Asian Pacific Journal of Tropical Biomedicine

[5] Kangabam Rajiv Das, Kangabam Medhabati, Khumukcham Nongaleima and Huidrom Sunitibala Devi. 2014. The Potential of Dark Purple Scented Rice- From Staple Food to Nutraceutical. Current World Environment Vol. 9(3), 867-876 (2014)

[6] Astawan, M. 2009. Bekatul Gizinya Kaya Betul. Diakses dari : http://www.kompas.com. Tanggal : 19 Pebruari 2012.

[7] Damayanthi, E., L. Kustiyah., M. Khalid., dan H. Farizal. 2010. Aktivitas Antioksidan Bekatul Lebih Tinggi Daripada Jus Tomat Dan Penurunan Aktivitas Antioksidan Serum Setelah Intervensi Minuman Kaya Antioksidan. Jurnal Gizi dan Pangan, 5(3): 205-210.

[8] Pasha, I., M.S. Butt, F.M. Anjum, dan N. Shahzadi. 2002. Effect of Dietetic Sweeteners an the Quality of Cookies. Int. J. Agric. Biol. 4(2). 245- 248.

[9] Apriyantono, A., D. Fardiaz, N.L. Puspitasari, Sedarnawati, dan S. Budiyanto. 1989. Petunjuk Laboratorium Analisis Pangan. Bogor : IPB.

[10] Asp, N., G. Johansson, Halmer, and Siljestrom. 1983. Rapid Enzimatic Assay of Insoluble and Soluble Dietary Fiber. Journal Agritech of Food Chemistry, 31: 476-482.

[11] Meilgaard, M., G.V. Civille, and B. Thomas Carr. 2007. Sensory Evaluation Techniques. 2 nd ed. CRC Press, Inc. London.

[12] Setyaningsih, D., A. Apriyantono, dan M.P. Sari. 2010. Analisis Sensori untuk Industri Pangan dan Agro. Bogor : IPB Press.

[13] Rimbawan dan A. Siagian. 2004. Indeks Glikemik Pangan. Penebar Swadaya, Jakarta.

[14] Yokoyama, W. 2004. Nutritional Properties of Rice and Rice Bran. In : Champagne, E.T. (Ed). Rice : Chemistry and Technology 3rd Edition. American Association of Cereal Chemists Inc., Minnesota.

[15] Marciani,L, Pritchard,S.E., Heller Woods, C., Costingan, C., Hoad, C.L., Gowland,P.A., \& Spiller,R.C. 2013. Delayed Gastric Emptying and Reduced Postprandial Small Bowel Water Content of Equicaloric Whole Meal Bread Versus Rice Meals in Healthy Subjects: Novel MRI Insights. European Journal of Clinical Nutrition, 67(7), 754-758.

[16] Nancy Saji, Nidhish Francis, Lachlan J. Schwarz, Christopher L. Blanchard and Abishek B. Santhakumar . 2019. Rice Bran Derived Bioactive Compounds Modulate Risk Factors of Cardiovascular Disease and Type 2 Diabetes Mellitus: An Updated Review. Nutrients 2019, 11, 2736; doi:10.3390/nu11112736

[17] Brennan,M.A., Derbyshire,E.J., Brennan C.S., \& Tiwari,B.K. 2012. Impact of Dietary Fibreenriched Ready-to-eat extruded Snacks on The Postprandial Glecaemic Respons of Non-diabetic Patiens. Molecular Nutrition \& Food Research, 56(5), 834-837.

[18] Vulholm,S., Arildsen Jakobsen,L.M.,Vejrum Sorensen,K., Kehlet,U., Raben,A.,\& Kristensen,M. 2014. Appetite and Food Intake After Consumtion of Sausages With 10\% Fat and Added Wheat or Rye Bran. Appetite, 73, 205-211. 